which accompanies their formation, possibly aided by gas absorption. No work has been done on films obtained by collecting zinc oxide smoke ${ }^{2}$. The present results show, therefore, that it is inadvisable to use films of zinc oxide, prepared in the manner described, for high-voltage calibration or measurement.

H. H. Wills Physical Laboratory,

V. E. Cosslett. University, Bristol. Oct. 31 .

Bragg, Phil. Mag., 39, 647; 1920.

Finch and Quarrell, Proc. Phys. Soc., 46, 148; 1934.

\section{Ascorbic Acid (Vitamin C) and Phytocarcinomata}

IN a previous communication ${ }^{1}$, I have given an account of a phytocarcinogenic effect of œestrus hormone on tomato plants. In a similar preliminary experiment using the same technique ${ }^{2}$ with tomato plants, about $55 \mathrm{~cm}$. high, the effect of ascorbic acid upon plant-tumour production has been investigated.

Immediately after the inoculation of fifteen plants with $B$. tumefaciens, a $1 / 10,000$ aqueous solution of ascorbic acid (kindly supplied by Prof. A. Szent. Györgyi) was introduced through a petiolar stump. The average total dose thus absorbed was about $27 \mathrm{ml}$. per plant during the period June 8-22, 1935. Five of the fifteen were tentatively given, on the first day of the experiment, $5 \mathrm{ml}$. of a concentrated $(5 / 1,000)$ solution of ascorbic acid. Although the petiolar stump, through which this dose was absorbed, plasmolysed and completely collapsed within 38 hours, no other toxie effects were observed. Afterwards, the dilute solution was given to these plants through another petiolar stump. Twenty-one plants were set up as controls, and treated with an equal amount of water.

At the first signs of necrosis of the experimental tumours, they were cut off and weighed. The average weight of the tumours per plant was: with ascorbic acid, 1.116 gm.; with water only, $0.857 \mathrm{gm}$. The mean weight of the tumours of the plants treated with ascorbic acid was about 27 per cent greater than that of the control plants, although the total amount of crystalline ascorbic acid administered throughout the treatment amounted only to about $2 \cdot 7$ mgm. per plant; owing to its rapid oxidation in solution, the amount actually absorbed is estimated to have been $40-50$ per cent less.

The hydrogen ion concentration of the sap of the treated plants and controls, and of the tumours severed from these plants, was as follows (mean values) :

\begin{tabular}{|c|c|c|c|}
\hline & $\begin{array}{l}\text { Concentration } \\
\text { of solution }\end{array}$ & $\begin{array}{l}p H \text { H } 24 \text { hours } \\
\text { after absorption } \\
\text { of first solution }\end{array}$ & $\begin{array}{c}p \mathrm{H} \text { at end of } \\
\text { experiment }\end{array}$ \\
\hline Leaves & $1 / 10,000$ & $5 \cdot 6$ & $5 \cdot 6$ \\
\hline & $5 / 1,000$ & $5 \cdot 4$ & \\
\hline $\begin{array}{l}\text { Leaves and } \\
\text { stem }\end{array}$ & $1 / 10,000$ & - & $5 \cdot 5$ \\
\hline Tumours & $\begin{array}{l}\text { 5/ } 1,000 \\
1 / 10,000\end{array}$ & 二 & $\begin{array}{l}5 \cdot 5 \\
5 \cdot 8\end{array}$ \\
\hline $\begin{array}{l}\text { Leaves } \\
\text { Leaves an }\end{array}$ & 0 (contre & $5 \cdot 6$ & $5 \cdot 6$ \\
\hline stem & 0 & - & $5 \cdot 5$ \\
\hline Tumours & 0 & - & $5 \cdot 8$ \\
\hline
\end{tabular}

With the exception of the slight lowering of the $p H$ of leaf-sap extracted twenty-four hours after the administration of the stronger solution of ascorbic acid, the acid does not appear to have affected the hydrogen ion concentration of the sap extracted from the treated plants. The greater alkalinity of tumour sap is a characteristic of most tumour tissues.
Histo-eytological examination of tumours from the treated and control plants gave no indication that the increased size of the tumours severed from treated plants was simply due to the stretching of the cells caused by a general stimulation of somatic growth under the influence of ascorbic acid ${ }^{3}$. As the size and arrangement of the cells and that of the phloemxylem elements were identical in the two, it is deduced that the treatment led to an increase of cell proliferation of the pathological tissues.

It is hoped to extend the range of the experiment outlined above, in order to test whether a parallelism exists, for plants, with the findings of Fodor and Kunos $^{4}$, Schroeder ${ }^{5}$, and Frisch and Willheim ${ }^{6}$, concerning the carcinogenic influence of ascorbic acid on animals.

LÁszló Havas.

Hungarian Biological Research Institute, Tihany, Hungary. Nov. 14.

'Havas, L., NAtURe, 136, 516, Sept. 28, 1935.

2 Havas, L., and Caldwell, J., Ann. Bot., 49, 731 ; 1935.

3 Havas, L., NATURE, 136, 435, Sept. 14, 1935.

Fodor, E., and Kunos, St., Z. Krebsforsch., 40, 484; 1935.

Schroeder, H., Klin. Wochenschr., 14, 484; 1935.

" Frisch, C., and Willheim, R., Biochem. Z., 277, 148; 1935.

\section{A New Type of Plant Lipochrome}

IN continuation of our investigations upon the Algæ $^{1}$, we have observed the presence of a peculiar carotenoid in the unsaponifiable fraction of one of the Cyanophycece (Myxophycea), namely, Rivularia nitida. The pigment, for which we propose the name myxoxanthin, crystallises from ether-methyl alcohol in deep copper-coloured needles, m.p. $117^{\circ}-118^{\circ}$ (uncorr.), and unlike any other phytocarotenoid hitherto isolated, exhibits only one absorption band, having its head at 488-490 $\mathrm{m} \mu$ in carbon disulphide. In this respect myxoxanthin resembles the Crustacean pigment astacene ${ }^{2}$; but unlike the latter, it has no acidic properties and is completely epiphasic when subjected to the Kraus partition between methyl alcohol and light petroleum. Its failure to yield a sodium salt precludes the possibility of its being hæmatochrome, which pigment is reputed to exist in certain Algæ and is likewise stated to possess only a single absorption band ${ }^{3}$.

We have failed to detect the presence of any hypophasic xanthophylls in Rivularia nitida, and the absence of these is, so far as we are aware, unique in plant life, although we have found that Trentepohlia aurea, a member of the Chlorophycea, contains only a minute amount of hypophasic xanthophylls, the yellow colour of the plant being due almost wholly to its high $\beta$-carotene content. We are at present engaged in collecting a larger amount of Rivularia nitida with a view to a closer characterisation of the new pigment.

I. M. Heilbron.

B. LyThGOE.

Chemical Department,

R. F. Phipers.

University,

Manchester. Nov. 28.

${ }^{1}$ Heilbron, Phipers and Wright, Nature, 133, 419; $1934 . J$. Chem. Soc., 1572 : 1935. Heilbron and Phipers, Biochem. J., 29, 1369 ; 1935. Heilbron, Parry and Phipers, Biochem. J., 29, ï376. $1382 ; 1935$

'Kuhn and Lederer, Berichte, 66, 488; 1933.

3 Kylin, Z. phys. Chem., 168, 39 ; 1927. 